\title{
EFL Learners' Note Taking: The Effect of Listening Questions and Activities
}

\author{
Masoud Zoghi ${ }^{1} \&$ Pooya Drood $^{1}$ \\ ${ }^{1}$ Department of ELT, Ahar Branch, Islamic Azad University, Ahar, Iran \\ Correspondence: Pooya Drood, Department of ELT, Ahar Branch, Islamic Azad University, Ahar, Iran. E-mail: \\ dr.m.zoghi@gmail.com or oldtiger16@yahoo.com
}

Received: September 26, 2016 Accepted: October 18, 2016 Online Published: January 12, 2017

doi:10.5539/ijel.v7n1p173 URL: http://dx.doi.org/10.5539/ijel.v7n1p173

\begin{abstract}
In this comparative study, an attempt was made to examine the effects of two types of listening questions and activities on the quantity of note taking of intermediate EFL learners. In so doing, the researchers selected a sample of 30 intermediate English language learners randomly assigned to two comparison groups-Multiple-choice Group and True-false Group. The instrument for data collection was note taking papers of students from which the total number of words for each language learner was calculated. Results showed that the True-false Group gained higher scores in note taking quantity as compared with Multiple-choice Group. Based on the results of this study, it is imperative that EFL teachers pay serious attention to the types of activities and questions used in class as they can have an influence on the ways foreign language learners use note taking as a learning strategy.
\end{abstract}

Keywords: listening, multiple-choice questions, note taking, true-false questions-strategy

\section{Introduction}

In today's world, note taking plays as a memory device to retain information. Note-taking application across variety of fields such as professional, academic, and personal spheres, has demonstrated its systematic role for retention of information (Kiewra, 1989). Note-taking is an important advantage and choosing the most appropriate method is critical to acquire and retain information. Note taking has obviously drawn the attention of specialists in the field of English language pedagogy. Admittedly, in the field of English for academic purposes, note-taking is viewed as a critical ability in addressing listening process (Flowerdew, 1994; Rost, 2002).

The significance of educating and learning of note assuming took a position in the field of exploration. The requirement for the learning and educating of note-taking is additionally reflected in reading material essayists either composing a listening course book particularly tending to note-taking (e.g., Contemporary Topics: Advanced Listening Comprehension by Beglar and Murray, 1993), or including note-taking as an important component in the textbooks (e.g., quest: Listening and Speaking in the Academic World, by Hartmann and Blass, 2000).

\subsection{Review of Literature}

The research on note-taking in L2 is handful (Flowerdew, 1994). Some studies investigating the relationship between note-taking (as opposed to no note-taking) and listening comprehension resulted in no significant relationship between the two (Dunkel, 1988; Hale \& Courtney, 1994; Chaudron, Loschky, \& Cook, 1994).

Note-taking is a significant aptitude to people in both scholastic and non-scholarly settings. Individuals take notes for a wide range of reasons, including: to learn, to upgrade long haul maintenance, and to record occasions. Note-taking permits individuals to outsource their recollections to an outside source (paper), and also make content express for future reference.

Notwithstanding helping understudies learn and recover data, note-taking can likewise be utilized as a part of expert settings to individuals settle on better choices, take care of issues, and work all the more effectively as a gathering. The demonstration of note-taking likewise enhances review of candidate actualities for employment questioners, while the demonstration of investigating notes enhances judgment exactness (selecting the best candidate) for questioners (Middendorf \& Macan, 2002). 
Among all the note-taking circumstances, scholarly note-taking is all the more frequently talked about in light of the fact that various scientists consider the relationship between note-taking and understudies' scholastic accomplishment, particularly on the post-optional level. For example, several researchers have examined college students' perceptions about note-taking (e.g., Reimer, Brimhall, Cao, \& O’Reilly, 2008; Meter, Yokoi, \& Pressley, 1994) and the role notes play in learning (e.g., Carter \& Van Matre, 1975; Knight \& McKelvie, 1986). These studies indicate that note-taking improves students' performance. For example, Bohay, Blakely, Tamplin, \& Radvansky (2011) found that note-taking improved a person's referential understanding of the described events.

All above mentioned issues focused on the importance of note taking and its different benefits in academic setting as well as helping language learners work on progressively in class. All these findings, on the other hand, take into account one-way experiment which is from note taking to output and how this note taking strategy can help and affects the performance of language learners. To my best knowledge, rarity of research in the opposite way (effects of types of activities on note taking) is apparent. The goal of this study is to provide insights into if note taking quantity as a strategy can be changed in relation to types of questions and activities in the classroom.

\subsection{Research Question and Hypothesis}

The present study attempted to answer the question raised about the quantity difference in note taking of EFL learners based on different question types and activities. The objective of the study can be expressed in the following question:

Do the notes taken by EFL learners differ in terms of their quantity in relation to multiple -choice and true- false questions?

According to the above mentioned question, the following research hypothesis was developed. The negative counterpart was the null one.

H0: Notes taken by EFL learners doesn't differ in terms of their quantity in relation to multiple -choice and truefalse questions.

\section{Methodology}

\subsection{Participants}

The participants in this study were 30 intermediate male students studying English in one of the language institutes which is a private language with main focus on communicative approach toward language learning and teaching in Tabriz, Iran. The participant's age range was between 16-22 years. The native language of participants was Azerbaijani, the regional language used for everyday communicational. Persian, the national language of Iranians, is used as official language for public life activities, especially schooling in Azerbaijani area in Iran and English was their third foreign language. The sample was selected out of a population of 40 intermediate students using the Preliminary English Test (PET). Those scored ranged from 50-60 out of 65 were selected to participate in the study.

\subsection{Instrumentations}

The preliminary English Test PET was used to assure the initial homogeneity of the groups in terms of their L2 proficiency. The participants' PET scores were entered into an independent samples t-test, the results of which confirmed the two groups' initial homogeneity.

\subsection{Procedures}

30 intermediate level students were participated. This level was chosen because the students at this level are familiar with almost all of the Basic English structures and they can handle listening tasks and produce complete sentences. At the beginning of the 5-week program the PET exam including three sections of listening, reading and writing were administered to assure the initial homogeneity of the groups in terms of their L2 proficiency. After being randomly assigned to two groups students were asked to answer the questions (activities) every session online being allowed to take notes. After each session papers used for taking notes were collected as the source for counting the words. At the end of the program the total number of words was calculated.

\section{Results}

\subsection{Investigating the Homogeneity of Groups}

In order to investigate the homogeneity of two groups, the researcher utilized an independent sample test to compare the means of each group's PET scores. Table 1 depicts the results of descriptive statistics and an independent t-test. The necessary condition for comparison of the means is the equality of variance in both groups, which is shown by Levene's for equality of variances. 
Table 1. Independent samples test for the homogeneity of groups

\begin{tabular}{|c|c|c|c|c|c|c|c|c|c|}
\hline & \multirow[t]{2}{*}{ Group } & \multirow[t]{2}{*}{$\mathrm{N}$} & \multirow[t]{2}{*}{ Mean } & \multirow[t]{2}{*}{$\begin{array}{l}\text { Std. } \\
\text { Deviation }\end{array}$} & \multicolumn{2}{|c|}{$\begin{array}{l}\text { Levene's test for equality } \\
\text { of variances }\end{array}$} & \multicolumn{3}{|c|}{ T-test for equality of means } \\
\hline & & & & & $\mathrm{F}$ & Sig. & $\mathrm{T}$ & $\mathrm{df}$ & Sig.(2-tailed) \\
\hline \multirow[t]{2}{*}{ PET scores } & Multiple-choice group & 15 & 54.800 & 3.054 & 1.293 & .263 & .507 & 38 & .615 \\
\hline & True-false & 15 & 54.350 & 2.540 & & & & & \\
\hline
\end{tabular}

As the results of Table 1 show, regarding the significance level of Leven's test (0.263), which is more than 0.05 , equality of variances is verified.

The mean score of the PET test in group 1 group is (54.8), and in group 2 group (54.3). Significance of the t-test was calculated, 0.615 . As the significance of t-test is higher than 0.05 , therefore equality of PET scores' means in two groups is not rejected .As a result, the means of PET scores in group do not have meaningful difference, so these two groups are homogeneous.

\subsection{Comparison of Mean Scores of Two Groups}

Table 2. Group statistics

\begin{tabular}{lllll}
\hline Groups & N & Mean & Std. Deviation & Std. Error Mean \\
\hline M G & 15 & 36.8000 & 6.31551 & 1.63066 \\
TF G & 15 & 41.7333 & 3.01109 & .77746 \\
\hline
\end{tabular}

Table 3. Independent samples t-test for the comparison of means in groups

\begin{tabular}{|c|c|c|c|c|c|c|c|c|c|}
\hline & \multicolumn{2}{|c|}{$\begin{array}{l}\text { Levene's test for } \\
\text { equality of variances }\end{array}$} & \multicolumn{7}{|c|}{ t-test for equality of means } \\
\hline & \multirow[t]{2}{*}{ F } & \multirow[t]{2}{*}{ Sig. } & \multirow[t]{2}{*}{$\mathrm{t}$} & \multirow[t]{2}{*}{ df } & \multirow[t]{2}{*}{$\begin{array}{l}\text { Sig. } \\
\text { (2-tailed) }\end{array}$} & \multirow[t]{2}{*}{$\begin{array}{l}\text { Mean } \\
\text { Difference }\end{array}$} & \multirow[t]{2}{*}{$\begin{array}{l}\text { Std. Error } \\
\text { Difference }\end{array}$} & \multicolumn{2}{|c|}{$\begin{array}{l}95 \% \text { Confidence Interval } \\
\text { of the Difference }\end{array}$} \\
\hline & & & & & & & & Lower & Upper \\
\hline $\begin{array}{l}\text { Equal variances } \\
\text { assumed }\end{array}$ & 4.157 & .051 & -2.731 & 28 & .011 & -4.93333 & 1.80651 & -8.63381 & -1.23286 \\
\hline $\begin{array}{l}\text { Equal variances not } \\
\text { assumed }\end{array}$ & & & -2.731 & 20.052 & .013 & -4.93333 & 1.80651 & -8.70103 & -1.16564 \\
\hline
\end{tabular}

Independent samples t-test was utilized to compare the performance of two groups. Again the necessary condition for comparing the mean differences is the equality of variances of groups. Therefore, Levene's $t$ for equality of variances was utilized to compare the variances of two groups. As the results of table 3 show, regarding the significance level of Leven's test $(\mathrm{P}>0.05, \mathrm{df}=28, \mathrm{t}=-2.73)$, (sig. .051) which is more than 0.05 , equality of variances is verified.

Mean scores for $M G$ is $(M=36.80, S D=6.31)$, and for $T F G$ is $(M=41.73, S D=3.01)$. Significance of the $t$-test is (0.011). Because the significance of t-test is smaller than 0.05 , therefore null hypothesis (equality of mean scores in two groups) is rejected. Consequently, mean scores of TF G is meaningfully higher than that of MG.

\section{Discussion}

This study attempted generally to investigate whether the notes taken by EFL learners differ according to the types of the questions and activities they were provided with. The result of the study revealed that English language learners that were asked to take notes while listening according to types of questions (true-false questions) had higher quantity of notes compared with those who were asked to answer the questions based on the multiple - choice questions in terms of total number of words.

The reason that the quantity of notes, in relation to the total number of words, was taken into account was that these types of notes can better be indicators of language learners' natural strategy facing with types of information being asked or problem-causing situations. In order to recall information best in later time learners make obvious the best way to achieve this goal. It is not something extant from the scratch. Note-taking is not as a matter of course an ability that understudies learn through experimentation amid their training (van der Meer, 
2012).

Of course recalling the information for language learners using notes is considered as one modes of learning. Learning can happen amid both the generation and audit of notes by permitting the learner to make associations between thought units and take part in profound preparing content (Bohay, 2011; Piolat, Olive, \& Kellogg, 2005). Because both multiple -choice questions and true-false questions have a comprehension nature they are assumed to require cognitive loading and consequently differs from one person to another. Of course the results of this study can't determine for sure the absolute criteria for evaluating the quantity of the notes. For the most part, notes are considered private and important just to the note-taker, making it substantially harder to set up a decent criteria for top notch notes (Piolat, 2005). In any case, a few researchers have contended that the most elevated quality or best notes are those that can be comprehended by somebody new to substance of the notes (Williams \& Eggert, 2002). The results of this study confirms the idea that note-taking, because of its dependence on working memory, makes the learner's WM limit basic for ideal note-taking, as both perception and generation forms (Pilot, 2005).

In sum, it seems that true-false based questions need more cognitive loading and consequently force the learners to recall more information by taking more notes in terms of the number words.

\section{Conclusion}

In terms of pedagogical practice, the most important contribution of this study is that it makes it clear the types of the questions and activities can be effective in the sense that quantity of notes taken by EFL learners were affected according to multiple - choice and true-false questions. There are certain likely implications taken from this study for language teachers and material preparation experts. Teachers can vary their questions in their daily teaching of listening tasks. Providing students with the opportunity to use their own strategy in listening tasks is well worthwhile. In terms of research methodology, investigation of the data revealed that categories of analysis can be extended beyond the global measure of units of information, meaning, discoursal features, lexical selection, collocations of the speech can also be investigated.

\section{References}

Beglar, D., \& Murray, N. (1993). Contemporary topics: advanced listening comprehension. White Plains: Longman.

Bohay, M., Blakely, D. P., Tamplin, A. K., \& Radvansky, G. A. (2011). Note taking, review, memory, and comprehension. The American Journal of Psychology, 124, 63-73. https://doi.org/10.5406/amerjpsyc.124.1.0063

Carter, J. F., \& Van Matre, N. H. (1975). Note taking versus note having. Journal of Educational Psychology, 67, 900-904. https://doi.org/10.1037/0022-0663.67.6.900

Chaudron, C., Loschky, L., \& Cook, J. (1994). Second language listening comprehension and lecture note-taking. In J. Flowerdew (Ed.), Academic listening: research perspectives. Cambridge: Cambridge University Press.

Dunkel, P. (1988). The content of L1 and L2 students' lecture notes and its relation to test performance. TESOL Quarterly, 22(2), 259-282. https://doi.org/10.2307/3586936

Flowerdew, J. (1994). Academic listening: research perspective. Cambridge: Cambridge University Press.

Hale, G. A., \& Courtney, R. (1994). The effects of note-taking on listening comprehension in the Test of English as a Foreign Language. Language Testing, 11(1), 29-48. https://doi.org/10.1177/026553229401100104

Hartmann, P., \& Blass, L. (2000). Quest: listening and speaking in the academic world. Boston: McGraw-Hill.

Kiewra, K. A. (1989). A review of note-taking: The encoding-storage paradigm and beyond. Educational Psychology Review, 1, 147-172. https://doi.org/10.1007/BF01326640

Knight, L. J., \& McKelvie, S. J. (1986). Effects of attendance, note-taking, and review on memory for a lecture: Encoding vs. external storage functions of notes. Canadian Behavioral Science, 18(1), 52-61. https://doi.org/10.1037/h0079957

Middendorf, C. H., \& Macan, T. H. (2002). Note-taking in the employment interview: Effects on recall and judgments. Journal of Applied Psychology, 87(2), 293-303. https://doi.org/10.1037/0021-9010.87.2.293

Piolat, A., Olive, T., \& Kellogg, R. T. (2005). Cognitive effort during note taking. Applied Cognitive Psychology, 19, 291-312. https://doi.org/10.1002/acp.1086

Reimer, Y. J., Brimhall, E., Cao, C., \& O'Reilly, K. (2008). Empirical user studies inform the design of an 
e-notetaking and information assimilation system for students in higher education. Computers \& Education, 52, 893-913. https://doi.org/10.1016/j.compedu.2008.12.013

Rost, M. (2002). Teaching and researching listening. London: Pearson Education.

Van der Meer, J. (2012). Students' note-taking challenges in the twenty-first century: Considerations for teachers and academic staff developers. Teaching in Higher Education, 17, 13-23. https://doi.org/10.1080/13562517.2011.590974

Van Meter, P., Yokoi, L., \& Pressley, M. (1994). College students' theory of note-taking derived from their perceptions of note-taking. Journal of Educational Psychology, 86(3), 323-338. https://doi.org/10.1037/0022-0663.86.3.323

Willams, R. L., \& Eggert, A. C. (2002). Note taking in college classes: Student patterns and instructional strategies. The Journal of General Education, 51, 173-199. https://doi.org/10.1353/jge.2003.0006

\section{Copyrights}

Copyright for this article is retained by the author(s), with first publication rights granted to the journal.

This is an open-access article distributed under the terms and conditions of the Creative Commons Attribution license (http://creativecommons.org/licenses/by/4.0/). 